\title{
MEADOWS OF THE NORTHERN LEFT-BANK FOREST- STEPPE: THE CLASS PHRAGMITO-MAGNOCARICETEA (UKRAINE)
}

\author{
A. P. Tertyshnyi, Candidate of Biological Sciences, Associate Professor, \\ orcid.org/0000-0002-5649-0323 \\ B. Ye. Yakubenko, Doctor of Biological Science, Professor, \\ orcid.org/0000-0002-1308-5723 \\ National University of Life and Environmental Sciences of Ukraine \\ E-mail: tertyshnyy@ukr.net
}

This paper reviews the classification scheme of riparian vegetation (the class Phragmito-Magnocaricetea) of the northern Left-Bank Forest-Steppe. The physical geography peculiarities of the region are described. The northern part of the study area shares a border with Polissya. The eastern part borders on the western spurs of the Central Russian Upland. In the western part the flat relief of the study area contains marshes. Meadows are mainly in the floodplains of the Uday, Oster, Romen, Sula, Seim rivers. In the study area the following associations are identified: Caricetum vesicariae Br.-Bl. et Denis 1926, Glycerietum fluitantis Wilzek 1935, Carici acutae-Glycerietum maximae (Jilek et Valisek 1964) Shelyag, V. SI. et Sipaylova 1985, Poetum palustris Resmerita et Ratiu 1974, Beckmannietum eruciformis $R$. Jovanovic 1958. These associations depend on the alliances Caricion gracilis Neuhäusl 1959 em. Balátová-Tuláčkova 1963, Sparganio-Glycerion fluitantis Br.-Bl. et Siss. in Boer 1942, Poion palustris Shelyag, V.Sl. et Sipaylova 1985 and on the orders Magnocaricetalia Pignatti 1953, Nasturtio-Glycerietalia Pignatti 1953 em. Kopecký 1961 in Kopecký et Hejný 1965, Galio palustre-Poetalia palustris V.SI. 1996. The floristic diversity of the class comprises 66 genera, 26 families, 104 species (100\%). Equisetophyta includes two species (1,92\%), Magnoliopsida - 60 species (57,69\%), Liliopsida-42 species (40,39\%). The class contains 22 syntaxa: three orders, three alliances, five associations, two subassociations, nine variants. The diversity of taxa and syntaxa of the class Phragmito-Magnocaricetea depends on the wide diversity of habitats.

Keywords: grassland communities, syntaxonomy, species.

Introduction. The study area is similar to the northern left-bank geobotanical district of the Forest-steppe province (Didux \& Shelyag-Sosonko, 2003), and covers about $5930 \mathrm{~km}^{2}(180 \mathrm{~km}$ from north to south and $70 \mathrm{~km}$ from west to east). According to the physical geogra- phy zoning of Ukraine the study area is located in the northern Near-Dnieper elevation of Forest-steppe zone (Marynych at al., 2003). Upland relief of the western part contains marshes and swamp saucer (Dmytriyeva, 1969), the eastern part borders on the western spurs of the Central 
Russian Upland. These peculiarities are caused by the influence of glacier and glacier-water flows (Grymalo, 1970).

Meadows of the study area cover narrow strips of the territory. Particularly these are the floodplains of the Uday, Oster, Romen, Sula, Seim rivers. According to our evaluation the natural and the semi-natural vegetation occupy about 181 thousand hectares $(3,1 \%)$ of the study area. Meadows cover about 53 thousand hectares of the region $(0,9$ $\%)$, forests - 119 (2\%), marches - 9 $(0,2 \%)$. Meadows had been sporadically researched earlier. The ecological conditions, geographical peculiarities and geobotanical description of the Left-Bank Forest Steppe vegetation were researched by Mrinskii (1971). The location of the flood plain meadows in the transverse and longitudinal profiles of the Seim river and their zonal specificity were investigated by Afanasyev (1976). The meadows of the southern districts of the Chernihiv region were studied by Mulyarchuk (1961, 1970). Solomakha (1982) described meadows of the Vorskla river basin. The vegetation of the Desna-Oster interfluve in the Chernihiv region was researched by Lukash in 1999. In Ukraine the mesic grassland vegetation (phytosociological class Molinio-Arrhenatheretea) was studied by Kuzemko (2012, 2016). The structure of the Molinio-Arrhenatheretea class was created for the the northern left-bank geobotanical district (Tertyshnyi, 2006). Nowadays it is important to identify the syntaxa of the meadow vegetation and its peculiarities.

The research object of our investigation is the meadow vegetation of the northern Left-Bank Forest-Steppe.

The aim is to create the syntaxonomical scheme of the Phragmito-Magnocaricetea class for better understernding of the flora pecularities.

\section{Materials and methods of research.} Latin names of species are given according to Sergei L. Mosyakin and Mykola M. Fedoronchuk (Mosyakin \& Fedoronchuk, 1999). Field flora and geobotanical study (2002-2018 years) is provided by traditional methods (Field geobotany, 1959, 1976; Rabotnov, 1987; Ramenskii, 1937; Viktorov et al., 1959; Yunatov, 1964). The area of plots for meadow vegetation constitutes 4-100 square metres. During reseach it was collected 863 relevés, which were processed using standard methodic of phytcoenotic tables transformation (Kosman at al., 1991; Sirenko, 1996). For higher syntaxa it is used Mucina et al. (2016) and Solomaha et al. (2017) to compare our results with a comprehensive, hierarchical, syntaxonomic system of alliances, orders and classes of Braun-Blanquet syntaxonomy for vascular plants.

Results and discussion. On the base of own field researches (2002-2018 years) and literature sources (Gomlya, 2005; Goncharenko, 2003; Karpenko \& Kovtun, 1996; Mulyarchuk, 1970; Potulnyczkyj, 1972) it is reviewed the main types of vegetation. As a result it is formed the syntaxonomical scheme of the class Phragmito-Magnocaricetea.

Syntaxonomical scheme of the class Phragmito-Magnocaricetea Klika in Klika et Novák 1941 of the northern Left-Bank Forest-Steppe

Magnocaricetalia Pignatti 1953

Caricion gracilis Neuhäusl 1959 em. Balátová-Tuláčkova 1963

Caricetum vesicariae Br.-Bl. et Denis 1926

C.v. caricetosum acutae subass.

C.v. typicum Br.-Bl. et Denis 1926

Nasturtio-Glycerietalia Pignatti 1953 em. Kopecký 1961 in Kopecký et Hejný 1965

Sparganio-Glycerion fluitantis Br.B1. et Siss. in Boer 1942 
Glycerietum fluitantis Wilzek 1935

G.f. var. Poa palustris

G.f. var. Agrostis stolonifera

Carici acutae-Glycerietum maximae (Jilek et Valisek 1964) Shelyag, V.Sl. et Sipaylova 1985

C.a.-G.m. var. Carex vesicaria

C.a.-G.m. var. Agrostis stolonifera

Galio palustre-Poetalia palustris V.S1. 1996

Poion palustris Shelyag, V.Sl. et Sipaylova 1985

Poetum palustris Resmerita et Ratiu 1974

P.p. var. Ptarmica vulgaris

P.p. var. Agrostis capillaris

P.p. var. Beckmannia eruciformis

Beckmannietum eruciformis R. Jovanovic 1958

B.e.var. Carex vulpina

B.e. var. typicum

The characteristic of syntaxa. The class Phragmito-Magnocaricetea comprises highly wetted habitats with communities of shallow water vegetation, bank of ponds, herbaceous marshlands, wet and marshland meadows (Yurkevich et al., 1975; Balátová-Tuláčková, 1965; Balátová-Tuláčková, 1983; BalátováTuláčková, 1985; Baryła, 1970; Ellenberg, 1952; Fagasiewicz, 1963).

In the study area the flora diversity of the class Phragmito-Magnocaricetea contains 104 species: Achillea submillefolium Klokov et Krytzka, Acorus calamus L., Agrostis canina L., A. capillaris L., A. stolonifera L., Alisma lanceolatum With., A. plantago-aquatica L., Allium angulosum L., Alopecurus aequalis Sobol., A. geniculatus L., $A$. pratensis L., Althaea officinalis L., Anchusa officinalis L., Beckmannia eruciformis (L.) Host, Bidens cernua L., $B$. tripartita L., Bolboschoenus maritimus (L.) Palla, Butomus umbellatus L., Calamagrostis canescens (Weber) Roth,
Calla palustris L., Caltha palustris L., Carex acuta L., C. cespitosa L., C. disticha Huds., C. hirta L., C. nigra (L.) Reichard, C. rostrata Stokes, C. vesicaria L., C. vulpina L., Centaurea jacea L., Cichorium intybus L., Cicuta virosa L., Coccyganthe flos-cuculi (L.) Fourr., Dactylorhiza majalis (Rchb.) P.F.Hunt \& Summerhayes, Deschampsia cespitosa (L.) P.Beauv., Echinochloa crusgalli (L.) P.Beauv., Eleocharis palustris (L.) Roem. et Schult., Elytrigia repens (L.) Roem. et Schult., Equisetum palustre L., E. pratense L., Eryngium planum L., Festuca pratensis Huds., Filipendula denudata (J.Presl \& C.Presl) Fritsch, F. ulmaria (L.) Maxim., Galium boreale L., G. palustre L., Geranium palustre L., G. pratense L., Glechoma hederacea L., Glyceria fluitans (L.) R. Br., G. maxima (C. Hartm.) Holmberg., Gratiola officinalis L., Hierochloë repens (Host) Beauv., Inula britannica L., Iris pseudacorus L., I. sibirica L., Juncus articulatus L., J. atratus Krock., J. inflexus L., Lathyrus palustris L., Leersia oryzoides (L.) Sw., Lycopus europaeus L., L. exaltatus L. f., Lysimachia nummularia L., L. vulgaris L., Lythrum salicaria L., L. virgatum L., Mentha aquatica L., M. arvensis L., Myosotis scorpioides L., Naumburgia thyrsiflora (L.) Rchb., Phalacroloma annuum (L.) Dumort., Phalaroides arundinacea (L.) Rausch., Phleum pratense L., Plantago lanceolata L., P. major L., Poa palustris L., Potentilla anserina L., P. erecta (L.) Raeusch, Ptarmica salicifolia (Besser) Serg., P. vulgaris Blackw. ex DC., Pulicaria vulgaris Gaertn., Ranunculus acris L., R. flammula L., R. repens L., Rumex acetosa L., $R$. confertus Willd., $R$. crispus L., R. hydrolapathum Huds., $R$. thyrsiflorus Fingerh., Scutellaria galericulata L., S. hastifolia L., Sium latifolium L., Stachys palustris L., Stel- 
laria graminea L., S. palustris Retz., Symphytum officinale L., Taraxacum officinale Wigg., Thalictrum lucidum L., Trifolium fragiferum L., T. repens L., Valeriana officinalis L., Veronica longifolia L., Vicia cracca L., 66 genera: Achillea L., Acorus L., Agrostis L., Alisma L., Allium L., Alopecurus L., Althaea L., Anchusa L., Beckmannia Host, Bidens L., Bolboschoenus (Asch.) Palla, Butomus L., Calamagrostis Adans., Calla L., Caltha L., Carex L., Centaurea L., Cichorium L., Erodium L'Her., Coccyganthe (Rchb.) Rchb., Dactylorhiza Neck. ex Nevski, Deschampsia P.Beauv., Echinochloa P.Beauv., Eleocharis R. Br., Elytrigia Desv., Equisetum L., Eryngium L., Festuca L., Filipendula Mill., Galium L., Geranium L., Glechoma L., Glyceria R. Br., Gratiola L., Hierochloë R. Br., Inula L., Iris L., Juncus L., Lathyrus L., Leersia Sw., Lycopus L., Lysimachia L., Lythrum L., Mentha L., Myosotis L., Naumburgia Moench, Phalacroloma Cass., Phleum L., Plantago L., Poa L., Potentilla L., Ptarmica Mill., Pulicaria Gaertn., Ranunculus L., Rumex L., Scutellaria L., Sium L., Stachys L., Stellaria L., Symphytum L., Taraxacum Weber, Thalictrum L., Trifolium L., Valeriana L., Veronica L., Vicia L. and 26 families: Apiaceae Lindl., Araceae Juss., Asphodelaceae Juss., Asteraceae Dumort., Boraginaceae Juss., Butomaceae Rich., Caryophyllaceae Juss., Coccyganthe (Rchb.) Rchb., Cyperaceae Juss., Equisetaceae Rich. ex DC., Fabaceae Lindl., Geraniaceae Juss., Juncaceae Juss., Lamiaceae Lindl., Lythraceae J.St.-Hil., Plantaginaceae Juss., Poaceae Barnhart., Polygonaceae Juss., Ranunculaceae Juss., Rosaceae Juss., Rubiaceae Juss., Scrophulariaceae Juss., Tiliaceae Juss., Valerianaceae Batsch, Verbenaceae J. St.-Hil.
The diagnostic species of the class are Alisma plantago-aquatica, Alopecurus pratensis, Carex nigra, Coccyganthe flos-cuculi, Eleocharis palustris, Galium palustre, Geranium palustre, Glyceria maxima, Iris pseudacorus, Juncus atratus, Lycopus europaeus, Rumex hydrolapathum, Sium latifolium, Stachys palustris. This class contains three orders: Magnocaricetalia, Nasturtio-Glycerietalia and Galio palustre-Poetalia palustris.

The order Magnocaricetalia comprises communities of the tall sedges on the herbaceous eutrophic marshlands and the floodplain marshy meadows of rivers (Balátová-Tuláčková, 1963; Balátová-Tuláčková, 1978; BalátováTuláčková, 1974; Balátová-Tuláčková, 1977; Blažková, 1973; Miljan, 1933; Špániková, 1971).

The diagnostic species are Agrostis canina, Carex vesicaria, C. vulpina, Cicuta virosa, Equisetum palustre, Lysimachia nummularia, Mentha aquatica, Myosotis scorpioides, Naumburgia thyrsiflora, Rumex crispus, Stellaria palustris, Symphytum officinale. In the study area, the order comprises one alliance.

The order Caricion gracilis contains communities of sedge marshlands and marshy meadows on the near-terrace depressions of floodplains and in the banks of ponds. The diagnostic species are Carex acuta, C. cespitosa, C. vesicaria, Lysimachia nummularia, Mentha aquatica, Peucedanum palustre. The order contains one association.

The association Caricetum vesicariae is formed by communities of the near-terrace and central parts of floodplains, periphery of marshes and floodplain reservoirs with silt marsh gley soils. Communities of the association were also found on the western part of the study area near the headwaters of 
the Uday and Oster rivers. The diagnostic speciesis is Carex vesicaria. This association includes two subassociations found in Belorussia in the territory of Berezin's biosphere reservation (Stepanovich et al., 2005).

Communities of the subassociation C.v. caricetosum acutae spread in the banks and riparian shallow water of the floodplain reservoirs. The diagnostic species are Carex acuta, C. cespitosa, Glyceria maxima, Phalaroides arundinacea. The total cover is $90-100 \%$. The cover of Carex vesicaria is 5-65\%, C. acuta $-5-25 \%$. The number of species in relevés is $21-27$.

The subassociation C.v. typicum includes communities of the flooded plots of the central and near-terrace parts of the floodplains. The diagnostic species is Carex vesicaria. The total cover is 90-95\%. The cover of Carex vesicaria is $15-45 \%$. The number of species in relevés is $15-29$.

The order Nasturtio-Glycerietalia includes communities of the tall hygrophilous gramineous plants spread on the banks of the floodplain reservoir, in the relief depressions of the central and near-terrace parts of the floodplains and in the perifery of marshes (Kucharski, 1999; Tüxen, 1937; Vicherek, 1958; Vicherek et al., 1969).

The diagnostic species are Butomus umbellatus, Glyceria fluitans, Phalaroides arundinacea, Ptarmica salicifolia. The order comprises two alliances.

The alliance Sparganio-Glycerion includes phytocoenoses of the shallow water and meadow-marshland vegetation in the flat depressions of floodplains with silt gley marsh soiles. The diagnostic species are Alismaplantago-aquatica, Alopecurus aequalis, Glyceria fluitans, G. maxima. The alliance comprises two associations.
The association Glycerietum fluitantis comprises communities spread in the relief depressions of floodplains with meadow-marsh and sod-gley soils. Communities of the association are mainly found in the western part of the study area near the headwaters of the Oster and Romen rivers. The diagnostic species is Glyceria fluitans. The association contains two variants.

The comunities of the variant $\boldsymbol{G} . \boldsymbol{f}$. var. Poa palustris are located in the flat relief of the near-terrace depressions of floodplains with meadow-marsh soils. The diagnostic species is Poa palustris. The total cover is $80-95 \%$. The cover of Glyceria fluitans is 5-45\%, Poa palustris - 5-25\%. The number of species in relevés is 19-22.

Communities of the variant $\boldsymbol{G} . \boldsymbol{f}$. var. Agrostis stolonifera are spread in the flat areas of slightly increased near-terrace depressions of floodplains with sod-gley soils. The diagnostic species is Agrostis stolonifera. The total cover is $85-95 \%$. The cover of Glyceria fluitans is 15-65\%, Agrostis stolonifera $5-25 \%$. The number of species in relevés is $17-25$.

The association Cariciacutae-Glycerietum maximae comprises communities spread in the flat relief depressions with meadow-marsh and sod-gley loam soils. Communities of the association are mainly found in the western part of the study area near the headwaters of the Oster and Romen rivers. The diagnostic species are Carex acuta, Glyceria maxima. The association comprises two variants.

The variant C.a.-G.m. var. Carex vesicaria contains communities spread in near-terrace depressions of river floodplains with meadow-marsh soils. The diagnostic species is Carex vesicaria. The total cover is $95-100 \%$. The cover of Carex acuta is 15-45\%, 
Glyceria maxima - 15-45\%, Carex vesicaria $-5-15 \%$. The number of species in relevés is $12-16$.

The variant C.a.-G.m. var. Agrostis stolonifera includes communities spread in the slihgtly deep depressions of floodplains with sod-gley loam soils. The diagnostic species is Agrostis stolonifera. The total cover is $95-100 \%$. The cover of Carex acuta is $5 \%$, Glyceria maxima - 15-45 \%, Agrostis stolonifera $-5-15 \%$. The number of species in relevés is $10-17$.

The order Galio palustre-Poetalia palustris comprises the small gramineous plants of the meadows with sodgley loam soils. The diagnostic species are Agrostis stolonifera, Gratiola officinalis. This order comprises one alliance.

The alliance Poion palustris contains communities spread in the flat relief depressions of the wet meadows of the central and near-terrace depressions of floodplains with sod gley loam soils. The diagnostic species of the allience coincide with the same ones for the order. In the study area two associations of the alliance Poion palustris are found.

The association Poetum palustris comprises communities spread in the near-terrace and the central parts floodplains with meadow-marshy and meadow-loam soils. They are mainly located in the eastern part of the study area between outflows of the Romen river and the town of Konotop. The diagnostic speciesis is Poa palustris.

Communities of the variant P.p.var. Ptarmica vulgaris are mainly found in the near-terrace part of floodplains with meadow-marsh soils. The diagnostic species is Ptarmica vulgaris. The total cover is $90 \%$. Cover of Poa palustris is 5-45\%, Ptarmica vulgaris - 15-35\%. The number of species in relevés is 16-18.
The variant P.p. var. Agrostis capillaris comprises communities of the central part of floodplains with meadow gley soils. The diagnostic species is Agrostis capillaris. The total cover is $95 \%$. The cover of Poa palustris is $25-$ $45 \%$, Agrostis capillaris - $15 \%$. The number of species in relevés is 15-17.

The variant P.p.var. Beckmannia eruciformis comprises communities of the flat relief depressions of floodplains with meadow-marsh soils. The diagnostic species is Beckmannia eruciformis. The total cover is $90-95 \%$. The cover of Poa palustris is $15-25 \%$, Beckmannia eruciformis - $15-25 \%$. The number of species in relevés is 15-21.

Communities of the association Beckmannietum eruciformis are located in the excessively wet depressions of meadow plots with low salinity, sod-gley and silt-gley soils. They are mainly spread on the eastern part of the study area between the outflows of the Romen river and the town of Konotop. The diagnostic species is Beckmannia eruciformis.

The variant B.e. var. Carex vulpina contains communities with the total cover of 90-100\%, the cover of Beckmannia eruciformis is $45-65 \%$, Carex vulpi$n a-15-25 \%$. The diagnostic species are Carex acuta, C. nigra, C. vulpina. The number of species in relevés is 18-27.

The variant B.e. var. typicum includes communities with the total cover of 90-95\%, the cover of Beckmannia eruciformis is $45-65 \%$. The diagnostic species is Beckmannia eruciformis. The number of species in relevés is 19-24.

Conclusions and opportunities. The floristic diversity of the class Phragmito-Magnocaricetea comprises 66 genera, 26 families, 104 species (100\%). Equisetophyta includes two species $(1,92 \%)$, Magnoliopsida - 60 species $(57,69 \%)$, Liliopsida -42 species $(40,39 \%)$. The 
class contains 22 syntaxa: three orders, three alliances, five associations, two subassociations, nine variants. The diversity of taxa and syntaxa of the class Phragmito-Magnocaricetea depends on the wide diversity of habitats.

\section{References}

Afanasyev, D. Ya. (1976). Zone specification and location of of zone meadows on the Longitudinal profile of the Seim river. Ukrainian Botany Journal, 33 (1), 58-63 [in Ukrainian].

Balátová-Tuláčková, E. (1963). Abhängigkeit einiger Magnocaricetalia- und Molinietalia-Gesellschaften vom Pufferungsvermögen ihrer Böden. Biológia, 18, 713-729.

Balátová-Tuláčková, E. (1978). Die Nass- und Feuchtwiesen Nordwest-Böhmens mit besonderer Berücksichtigung der Magnocaricetalia-Gesellschaften. Rozp. Čes. Akad. VĚD, 88 (3), 1-113.

Balátová-Tuláčková, E. (1965). Die Sumpf- und Wiesenpflanzengelellschaften der Mineralböden südlich des Zábřek bei Hlučin. Vegetatio, 13, (1), 1-51.

Balátová-Tuláčková, E. (1991). Feuchtwiesen des Brdy-Berglandes und seiner Randgebiete (Mittelböhmen). Folia geobotanica et phytotaxonomica, 26, (1), 1-79.

Balátová-Tuláčková, E. (1983). Feuchtwiesen des Landschaftschutzgebietes Jiserské hory. I. Folia geobotanica et phytotaxonomica, 19, (1), 1-112.

Balátová-Tuláčková, E. (1985). Feuchtwiesen des Landschaftschutzgebietes Kokořinsko (Mittelböhmen). Mitteilungen der Floristisch-soziologischen Arbeitsgemeinschaft, 5, 217-231.

Balátová-Tuláčková, E. (1974). Mokré a vlhké louky v širším okolí Třebíče. Acta Soc.Sci.natur.Mus.Morav.occid. Třebíč, 9, 7-18.

Balátová-Tuláčková, E. (1981). Phytozönologische und synökologische Characteristik der Feuchtwiesen NW-Böhmens. Rozpravy Československé Akad. Véd, 91, 3-90.
Balátová-Tuláčková, E., Zelená, V., \& Tesařová, M. (1977). Synökologische Charakteristik einiger wichtiger Wiesentypen des Naturschutzgebietes "Ždárské vrchy". Rozpravy ČSAV, 87 (5), 115.

Baryła, R. (1970). Zbioroviska roślinne w dolinie rzeki Giełczwi i Radomki. Annales UMSC. Sect. E, 25, 167-186.

Blažková, D. (1973). Pflanzensociologische Studie über die Wiesen der Südböhmischen Becken. Studie ČSAV, 10, 170

Didukh, Ya. P., \& Shelyag-Sosonko, Yu. R. (2003). Geobotanical zonning of Ukraine and bordering territories. Ukrainian Botany Journal, 60 (1), 6-17 [in Ukrainian].

Dmytriyeva, V. I. (1969). The soils of Chernihiv region. Publisher Urozhaj, Kyiv [in Ukrainian].

Ellenberg, H. (1952). Wiesen und Weiden und ihre standörtliche Bewertung. Landwirtschaftliche Pflanzensozie. II. Publisher Ulmer, Stuttgart.

Fagasiewicz, L. (1963). Łąki doliny Pilicy na odcinku od Przedborza do Ujścia. Pr.Wydz. 3 七TN, 89.

Field geobotany. (1959). Academy of Science of USSR Publishing House, Moscow-Leningrad: Volume I [in Russian].

Field geobotany. (1976). Academy of Science of USSR Publishing House, Moscow-Leningrad: Volume $V$ [in Russian].

Gomlya, L. M. (2005). Vegetation of the Horol river valley. Ukrainian fitocoenology collection, series A, issue 1 (22), Publisher Fitosociocentre, Kyiv [in Ukrainian].

Goncharenko, I. V. (2003). Analysis of plant cover of north-east Forest Steppe of Ukraine. Ukrainian fitocoenology collection, series A, issue 1 (19). Publisher Fitosociocentre, Kyiv [in Ukrainian].

Grymalo, O. F. (1970). The soils of Sumy region. Publisher Prapor, Kharkiv [in Ukrainian].

Karpenko, K. K., \& Kovtun, V. A. (1996). Vegetation of Sumy region and its modern condition and problems of preservations. Condition of natural environment and problems 
of its preservation on Sumy region. Book 1 , 33-59 [in Ukrainian].

Kosman, E. G., Sirenko, I. P., Solomakha, V. A. \& Shelyag-Sosonko, Y. R. (1991). New computer method of processing of the plant community relevés. Ukrainian Botany Journal, 48, (2), 98-104 [in Ukrainian].

Kucharski, L. (1999). Szata roślinna łąk Polski Środkowej i jej zmiany w XX stuleciu. Wyd. Uniwersytetu Łódzkiego, Łódz.

Kuzemko, A. A. (2016). Classification of the class Molinio-Arrhenatheretea in the forest and forest-steppe zones of Ukraine. Phytocoenologia, 46 (3), 241-256.

Kuzemko, A. A. (2012). Ukrainian Grasslands Database. Biodiversity \& Ecology, 4, 430.

Lukash, O. V. (1999). The vegetation, floristic and sosology peculieritis of the Desna-Oster interfluve: M.G. Kholodny Institute of Botany of National Academy of Sciences of Ukraine, Kyiv [in Ukrainian].

Marynych, O. M., Parxomenko, G. O., Petrenko, O. M., \& Tyshhenko, P. G. (2003). Improved scheme of physico-geographical zoning of Ukraine. Ukrainian Geographical Journal, 1, 16-20 [in Ukrainian].

Miljan, A. (1933). Vegetationsuntersuchungen an Naturwiesen und Seen im Otepääschen Moränen-Gebiete Estlands. Acta Comment. Univ.Tartu (Dorpat), 25, Tartu.

Mirkin, B. M., Kononov, K. E., Gogoleva, P. A., Burtseva, E. I., \& Naumova, L. G. (1992). The floodplain grasslands of the Middle Lena-river. I. General characteristic and ordination. Folia Geobot. Phytotax., 27 (3), 225-245.

Mirkin, B. M., Kononov, K. E., Gogoleva, P. A., Burtseva, E. I., \& Naumova, L. G. (1992). The floodplain grasslands of the Middle Lena-river. II. Classification. Folia Geobot. Phytotax., 27 (3), 247-300.

Mosyakin, S. L., \& Fedoronchuk, M. M. (1999). Vascular plants of Ukraine. A nomenclatural checklist, Kyiv.

Mrinskii, O. P. (1971). Botanical and geographical essay of Left Forest Steppe of Ukraine: M.G. Kholodny Institute of Botany of Na- tional Academy of Sciences of Ukraine, Kyiv [in Russian].

Mucina, L., Bültmann, H., Dierßen, K., Theurillat, J.-P., Dengler, J., Čarni, A., Šumberová, K., Raus, T., Di Pietro, R., (...) \& Tichý, L. (2016). Vegetation of Europe: Hierarchical floristic classification system of plant, lichen, and algal communities. Applied Vegetation Science, 19 (1).

Mulyarchuk, S. O. (1961). Lowlands saline meadows of Ghernigiv region. Ukrainian Botany Journal, 28 (4), 81-90 [in Ukrainian].

Mulyarchuk, S. O. (1970). Vegetation of Chernihiv region. Publisher High school, Kyiv [in Ukrainian].

Potulnyczkyj, P. M. (1972). Field workshop on botany. Publisher High school, Kyiv [in Ukrainian].

Rabotnov, T. A. (1987). Experimental phytocenology. MSU Publishing House, Moscow [in Russian].

Ramenskii, L. G. (1937). An inventory and a catalogue of vegetation on the base of cover method. Publisher the Lenin National Academy for Agriculture Sciences, Moscow [in Russian].

Sirenko, I. P. (1996). Creation of Databases for Floristic and Phytocoenologic Researches. Ukranian phytocoenology collection, series $A$, issue 1, 9-11.

Solomakha, V. A. (1984). Meadow vegetation changes of Voskla's floodplain. Ukrainian Botany Journal, 41 (3), 23-28 [in Ukrainian]. Solomakha, V. A. (1982). Meadow vegetation of Vorskla's floodplain and ways of its enhancing productivity: M.M.Gryshko National botanical garden NAS of Ukraine, Kyiv [in Russian].

Solomakha, I. V., Shevchyk, V. L., \& Solomakha, V. A. (2017). Review of the higher vegetation units and diagnostic species of Ukraine according to the Braun-Blanquet approach. Publisher Phytosociocenter, Kyiv [in Ukrainian].

Špániková, A. (1971). Fytocenologická štúdia lúk juhozápadnej časti Košickej kotliny. Biol. Práce,17 (2). 
Stepanovich, I. M., Ivkovich, E. N., Stepanovich, E. F., \& Avtushko, S. A. (2005). Herbal communities of the Berezinsky Biosphere Reserve: strucrure, productivity, state [in Russian].

Tertyshnyi, A. P. (2006). Syntaxonomical scheme of the class Molinio-Arrhenatheretea R.Tx. 1937 of the Northern Left-Bank geobotanical district of the Forest Steppe of Ukraine. Contemporary problems of botany, ecology and biotechnology. Materials of International Scientific Conference of young scientists-botanists. Publisher Phytosociocentre, Kyiv [in Ukrainian].

Tüxen, R. (1937). Die Pflanzengesellschaften Nordwestdeutschlands. Mitt.Flor.-Soz.Arbeitsgem.Niedersachsen, 3.

Vicherek, J. (1958). Rostlinná společenstva rašelinných luk u Vidnavy. Př́rod. Sborn. Ostrav. Kraje, 19 (2).
Vicherek, J., \& Koráb, J. (1969). Über die Pflanzengelellschaften der Niedermoor- und Wiesenvegetation in der Umgebung von Svitavy und Moravská Třebová. Preslia. 41, 273-283.

Viktorov, S. V., Vostokova, E. A., \& Vyshivkin, D. D. (1959). Short manual to geobotanical work. Publishing House MSU, Moscow [in Russian].

Yunatov, A. A. (1964). The types and content of geobotanical studies. Selection of sample plots and environmental profiles. Field geobotany. Publisher Science, Moscow-Leningrad: Volume 3, 9-36 [in Russian].

Yurkevich, I. D., Burtys, N. A., \& Shcherbach, S. R. (1975). Associations of herbal marshes of upstream floodplain of the Berezyna river, 4, 79-105 [in Russian].

\section{А. П. Тертишний, Б. Є. Якубенко (2019). Луки північної частини лівобережного Лісостепу України: клас Phragmito-Magnocaricetea. UKRAINIAN JOURNAL OF FOREST AND WOOD SCIENCE, 10(3):53-61.}

http://dx.doi.org/10.31548/forest2019.03.053.

у статті наведено класифікаційну схему прибережно-водної рослинності (Клас Phragmito-Magnocaricetea) північної частини лівобережного Лісостепу України. Подано фізикогеограрічні особливості вказаного регіону. Східна частина території досліджень межує на півночі з західними відрогами Середньоросійської височини. На рівнинному рельєфі західної частини регіону трапляються болота. Луки збереглися перевањно взаплавах річок Удай, Остер, Ромен, Сула, Сейм.

Hа території регіону виявлені такі асоиіації класу Phragmito-Magnocaricetea: Caricetum vesicariae Br.-Bl. et Denis 1926, Glycerietum fluitantis Wilzek 1935, Carici acutae-Glycerietum maximae (Jilek et Valisek 1964) Shelyag, V.Sl. et Sipaylova 1985, Poetum palustris Resmerita et Ratiu 1974, Beckmannietum eruciformis R. Jovanovic 1958. Вказані асоиіації входять до наступних союзів: Caricion gracilis Neuhäusl 1959 em. Balátová-Tuláčkova 1963, Sparganio-Glycerion fluitantis Br-Bl. et Siss. in Boer 1942, Poion palustris Shelyag, V.Sl. et Sipaylova 1985 and on the orders - Magnocaricetalia Pignatti 1953, Nasturtio-Glycerietalia Pignatti 1953 em. Kopecký 1961 in Kopecký et Hejný 1965, Galio palustre-Poetalia palustris V.SI. 1996. Флористичну різноманітність класу Phragmito-Magnocaricetea формує 104 види, 66 родів, 26 родин. Equisetophyta містить два види (1,92 \%), Magnoliopsida - 60 видів (57,69\%), Liliopsida-42 види (40,39\%). До класу входить 22 синтаксони: три порядки, три союзи, п'ять асоціацій, дві субасочіації та дев'ять варіантів. Таксономічна та синтаксономічна різноманітність класу Phragmito-Magnocaricetea залежить від різноманітності природних оселищ.

Ключові слова: рослинні угруповання, синтаксономія, види рослин.

Отримано: 26.03.2019p. 